\title{
Simple workflow for genome and methylation analyses of ejaculated bovine spermatozoa with low sperm input
}

\author{
Bradford W Daigneault*, , Sandeep K Rajput ${ }^{2}$ \& George W Smith'
}

\begin{abstract}
We developed a simplified workflow of gDNA extraction from ejaculated bovine sperm using a low total number of sperm and a short time frame that yields high-quality DNA suitable for downstream methylation and genome analyses. These techniques have broad implications in human biomedical sciences and agriculture, including clinical diagnoses of infertility, the identification of single-nucleotide polymorphisms and aberrant methylation patterns that can impact fertility, lower embryo development and contribute to heritable disease. The methods described here provide a reliable, simplistic approach for analyzing both the genomic and epigenomic status of whole sperm ejaculates that can be adapted for laboratory diagnostics, clinical reproductive practice and basic research.
\end{abstract}

\section{METHOD SUMMARY}

We developed a cost-effective, user-friendly and reliable protocol (see Supplementary data) for DNA extraction from low-input samples of frozen-thawed bovine sperm, with a simple workflow for PCR amplification, bisulfite conversion and methylation analyses of individual amplicons.

\section{KEYWORDS}

bisulfite $\cdot$ DNA $\cdot$ epigenome $\cdot$ fertility - forensic $\cdot$ methylation - oligospermia - sequencing $\bullet$ sperm

${ }^{1}$ Department of Animal Science, Michigan State University, East Lansing, MI 48879, USA; ${ }^{2}$ Colorado Center for Reproductive Medicine, Lone Tree, C0 80124, USA; *Author for correspondence: brad.daigneault@ufl.edu

BioTechniques 68: 155-158 (March 2020) 10.2144/btn-2019-0121
Genomic and epigenomic analyses of sperm DNA are increasingly necessary techniques, with broad applications that include fertility diagnostics, forensic analyses and basic research [1,2]. Additionally, male infertility is a well-recognized concern that contributes to failed pregnancies in humans and agricultural animals [3]. Alterations to the genome or DNA methylation status of sperm can impact sperm function and embryo development [4]. Recent evidence suggests that aberrant methylation of spermatozoa inhibits proper sperm function and results in lower embryo survival [5]. Importantly, both sperm number and processing time are limiting factors that can influence downstream analyses. Simplified methods for gDNA extraction of sperm followed by successful bisulfite conversion, PCR amplification and downstream sequencing are needed to improve the workflow in clinical settings and provide more rigorous analyses with minimal processing times. However, extraction of DNA from sperm presents unique challenges that differ from somatic cells, including an acrosomal barrier and protamine compaction of chromatin that often results in low DNA yield [6-8]. Some protocols have been developed to address these challenges; however, most involve prolonged incubation times, proprietary reagents and high numbers of total sperm input that may be incompatible with available material [9]. Our goal was to simplify the extraction process and to shorten the time required for DNA extraction of mammalian sperm, while maintaining sufficient yield for downstream genome and methylation analyses. We developed a commercially viable column-based protocol to meet these objectives that require minimal sperm input conducive to in vitro fertilization techniques and a short, single-day extraction process that is compatible for downstream genomic and epigenomic analyses (Figure 1).

Unless otherwise specified, reagents were purchased from Sigma-Aldrich (MO, USA). Primers for PCR amplification are shown in Table 1. Isolated DNA was subjected to bisulfite conversion followed by purification using the EpiTect Bisulfite Kit (cat. no. 59104) and the QIAquick PCR Purification Kit (cat. no. 28104; both Qiagen, Hilden, Germany).

Frozen sperm from two different bulls (CentralStar Cooperative, Inc., MI, USA) were pooled for experiment with analyses conducted by the addition of technical replicates. Sperm were thawed in a water bath at $37^{\circ} \mathrm{C}$ for $30 \mathrm{~s}$ and then purified using a 45:90 Percoll gradient for experiment [10]. Purified sperm were pooled from two bulls, extended to $4 \times 10^{6}-4 \times 10^{2}$ total motile sperm by serial dilution in $400 \mu$ volumes and placed in a Tyrode albumin lactate pyruvate medium [11]. Sperm aliquots were added to $3.6 \mathrm{ml}$ of sperm wash (SW) reagent buffer $(150 \mathrm{mM} \mathrm{NaCl}$ and $10 \mathrm{mM}$ EDTA [pH 8.0]) in 10-ml Eppendorf tubes. Samples were vortexed for $10 \mathrm{~s}$ at full speed and then centrifuged at $2500 \times g$ for $5 \mathrm{~min}$. The supernatant was removed to approximately $1.0 \mathrm{ml}$, and the remaining sperm sample was transferred to a 2.0-ml microcentrifuge and centrifuged at $17,000 \times \mathrm{g}$ for $2 \mathrm{~min}$ to obtain a sperm pellet. All supernatants were removed, and the sperm pellet resuspended in $220 \mu$ of sperm lysis (SL) buffer (100 mM Tris-Cl, 10 mM EDTA, 500 mM NaCl, 1\% SDS). After adding $30 \mu \mathrm{l}$ of DDT ( $100 \mathrm{mM}$ final) and $50 \mu \mathrm{l}$ of proteinase $\mathrm{K}(40 \mathrm{mg} / \mathrm{ml})$, samples were incubated at $55^{\circ} \mathrm{C}$ for $2 \mathrm{~h}$. After incubation, $500 \mu$ l of buffer $\mathrm{E}$ ( $5 \mathrm{M}$ guanidium thiocyanate, $50 \mathrm{mM}$ Tris- $\mathrm{HCl}[\mathrm{pH}$ 8.0] and $25 \mathrm{mM}$ $\mathrm{NaCl}$ ) was added with an additional 10-min incubation period at $55^{\circ} \mathrm{C}$ for $10 \mathrm{~min}$. Ethanol $(400 \mu \mathrm{l})$ was added to the sperm lysate and passed through QIAamp Mini columns (Qiagen) by centrifugation at $9000 \mathrm{rpm}$ for $1 \mathrm{~min}$. Flow-through was discarded. A total of $500 \mu$ l of reagent WB1 (3 M guanidium thiocyanate, $100 \mathrm{mM}$ Tris-HCl [pH 8.0], $20 \mathrm{mM}$ EDTA and $50 \%$ EtOH) buffer was added and centrifuged again. Buffer WB2 (10 mM Tris- $\mathrm{HCl}$ [pH 7.4], $1 \mathrm{mM}$ EDTA, $100 \mathrm{mM} \mathrm{NaCl}$ and 80\% EtOH) was then added in $500 \mu$ l volumes 


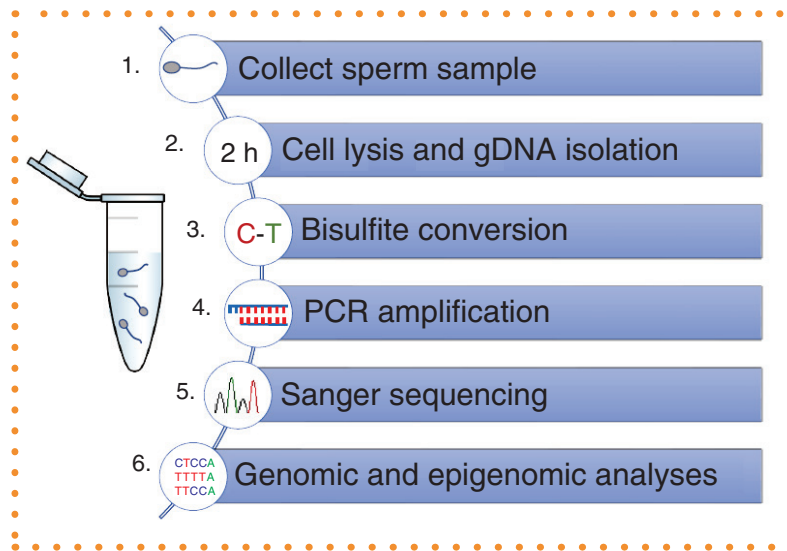

Figure 1. Workflow for gDNA extraction of mammalian sperm for genomic and epigenomic analyses of whole sperm ejaculates.

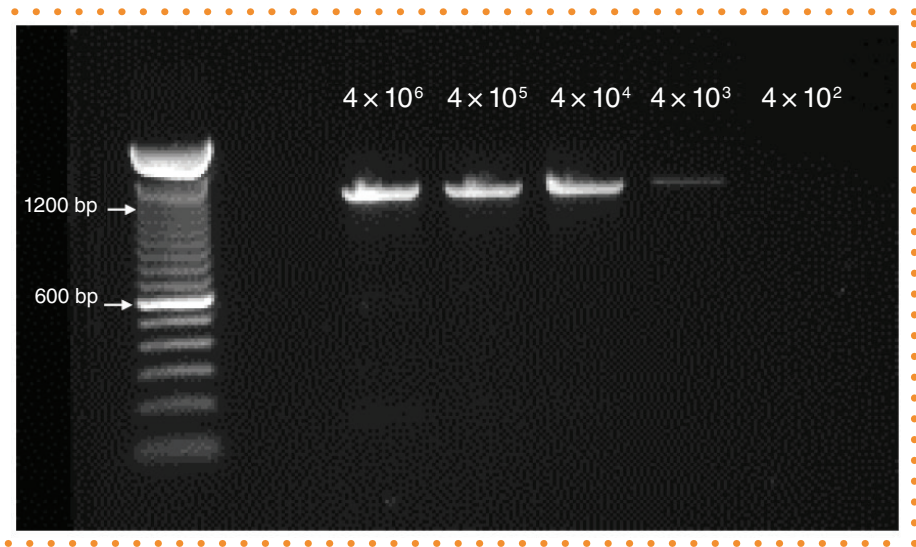

Figure 2. Sensitivity assay of gDNA extraction from whole sperm. PCR product amplification of the POU5F1 locus of pooled bull sperm following serial dilution of $4 \times 10^{6}-4 \times 10^{2}$ total motile sperm ( $n=$ pooled bull sperm from two bulls). and centrifuged for an additional $1 \mathrm{~min}$ at $9000 \mathrm{rpm}$. Buffer WB2 $(750 \mu \mathrm{l})$ was added to the column and centrifuged at $14,000 \mathrm{rpm}$ for $3 \mathrm{~min}$. Columns were transferred to a new collection tube for an additional $1 \mathrm{~min}$ of centrifugation at maximum speed. For DNA elution, columns were transferred to clean 2.0- $\mathrm{ml}$ collection tubes and eluted twice in
$23 \mu \mathrm{l}$ of RNAse-free $\mathrm{H}_{2} \mathrm{O}$ and quantified by NanoDrop (Table 2).

The assay sensitivity of gDNA isolation from whole bull sperm was tested by amplification of a 1242-base pair (bp) region of exon 2 from the POU5F1 locus using a single reaction in 40- $\mu$ l volumes consisting of $20 \mu \mathrm{l}$ of GoTaq Hot Start Green Master Mix (2x;

\section{Table 1. Primer sequences used for PCR amplification of bull sperm.}

\begin{tabular}{|l|l|l|l|l|l|}
\hline Primer & Sense & Length (nt) \\
\hline NRF1 Primer sequences (NCBI: AC_000180.1) & \\
\hline Bisulfite: & Exon 1 & F & GAGAAGTAAAGGTTATTTTAAAGG & \\
\hline & & R & TAAAACACTCACCTCAAAAC & 558 \\
\hline Bisulfite seq: & Exon 1 & F & AGGGAAATGTGAATGTAGGGAGA & \\
\hline POU5F1 Primer sequences (NCBI: AC_000180.1) & \\
\hline & Exon 2 & F & CGTGTGTTTGTGAATGTGCG & 1242 \\
\hline & & R & GGAAAGAAATGGGCAGGCAA & \\
\hline \\
seq: Sequence.
\end{tabular}

Table 2. Quality and quantity of sperm DNA after isolation of genomic, bisulfite-converted and PCR-amplified DNA from pooled bull sperm ( $n=6$ samples).

\begin{tabular}{|l|l|l|lll|} 
& \multicolumn{2}{c}{ gDNA } & \multicolumn{2}{c}{ Bisulfite-converted DNA } \\
\cline { 2 - 3 } \cline { 5 - 5 } Sample & $\begin{array}{l}\text { Input (number of } \\
\text { motile sperm) }\end{array}$ & Output (ng) & \multicolumn{2}{c}{ Output (ng) } & PCR output (ng) \\
\hline 1 & $4 \times 10^{6}$ & 1616 & 762 & 789 \\
\hline 2 & $4 \times 10^{6}$ & 1698 & 1540 & 1090 \\
\hline 3 & $4 \times 10^{6}$ & 1316 & 1018 & 1010 \\
\hline 4 & $4 \times 10^{6}$ & 832 & 480 & 1068 \\
\hline 5 & $4 \times 10^{6}$ & 1962 & 1418 & 537 \\
\hline 6 & $4 \times 10^{6}$ & 866 & 620 & 876 \\
\hline
\end{tabular}

cat. no. M5123; Promega, WI, USA) with the addition of $0.8 \mu \mathrm{l}(4 \mathrm{pM})$ of forward and reverse primer each and $18.4 \mu \mathrm{l}$ of template (up to $50 \mathrm{ng}$ ) and water. For samples with DNA isolation below limitations of NanoDrop detection, $18.4 \mu$ l of presumed DNA elution was used. PCR conditions were as follows: $95^{\circ} \mathrm{C}$ for $3 \mathrm{~min}$, followed by 35 cycles of $95^{\circ} \mathrm{C}$ for $30 \mathrm{~s}, 56^{\circ} \mathrm{C}$ for $30 \mathrm{~s}, 72^{\circ} \mathrm{C}$ for $30 \mathrm{~s}$ and a final extension of $72^{\circ} \mathrm{C}$ for $7 \mathrm{~min}$. After amplification, $5 \mu$ l of PCR product was loaded onto a $0.9 \%$ agarose gel containing $\operatorname{EtBr}(0.5 \mu \mathrm{g} / \mathrm{ml})$ and $0.5 \times$ TBE running buffer ( $40 \mathrm{mM}$ Tris-Cl, $45 \mathrm{mM}$ boric acid and $1 \mathrm{mM} \mathrm{EDTA}$ ) and run at $95 \mathrm{~V}$ for $1 \mathrm{~h}$ (Figure 2).

For bisulfite conversion of isolated gDNA, $50 \mathrm{ng}$ (up to $20 \mu \mathrm{l}$ ) of extracted DNA was placed with $85 \mu \mathrm{l}$ of bisulfite reaction mixture and $35 \mu$ l of DNA protect buffer in a $200-\mu l$ PCR tube. Tubes were mixed by inversion, briefly centrifuged and placed in a thermocycler to carry out cytosine conversion using the following manufacture-specified reaction: $95^{\circ} \mathrm{C}$ for $5 \mathrm{~min}, 60^{\circ} \mathrm{C}$ for $25 \mathrm{~min}, 95^{\circ} \mathrm{C}$ for $5 \mathrm{~min}, 60^{\circ} \mathrm{C}$ for $85 \mathrm{~min}, 95^{\circ} \mathrm{C}$ for $5 \mathrm{~min}$ and $60^{\circ} \mathrm{C}$ for $175 \mathrm{~min}$. Cleanup and isolation of bisulfite-converted DNA was continued according to kit-specified guidelines, with final elutions performed in $23 \mu$ of RNAsefree $\mathrm{H}_{2} \mathrm{O}$. Quantification of converted DNA was measured by NanoDrop, using RNA (Factor 40) settings that resemble converted DNA. Converted DNA was held at $10^{\circ} \mathrm{C}$ overnight or stored at $-20^{\circ} \mathrm{C}$, until quantification and further processing (Table 2).

Bisulfite-converted DNA was used for PCR amplification and Sanger sequencing to analyze the methylation pattern of the bovine NRF1 locus (Figure 3A). NRF1 primers 


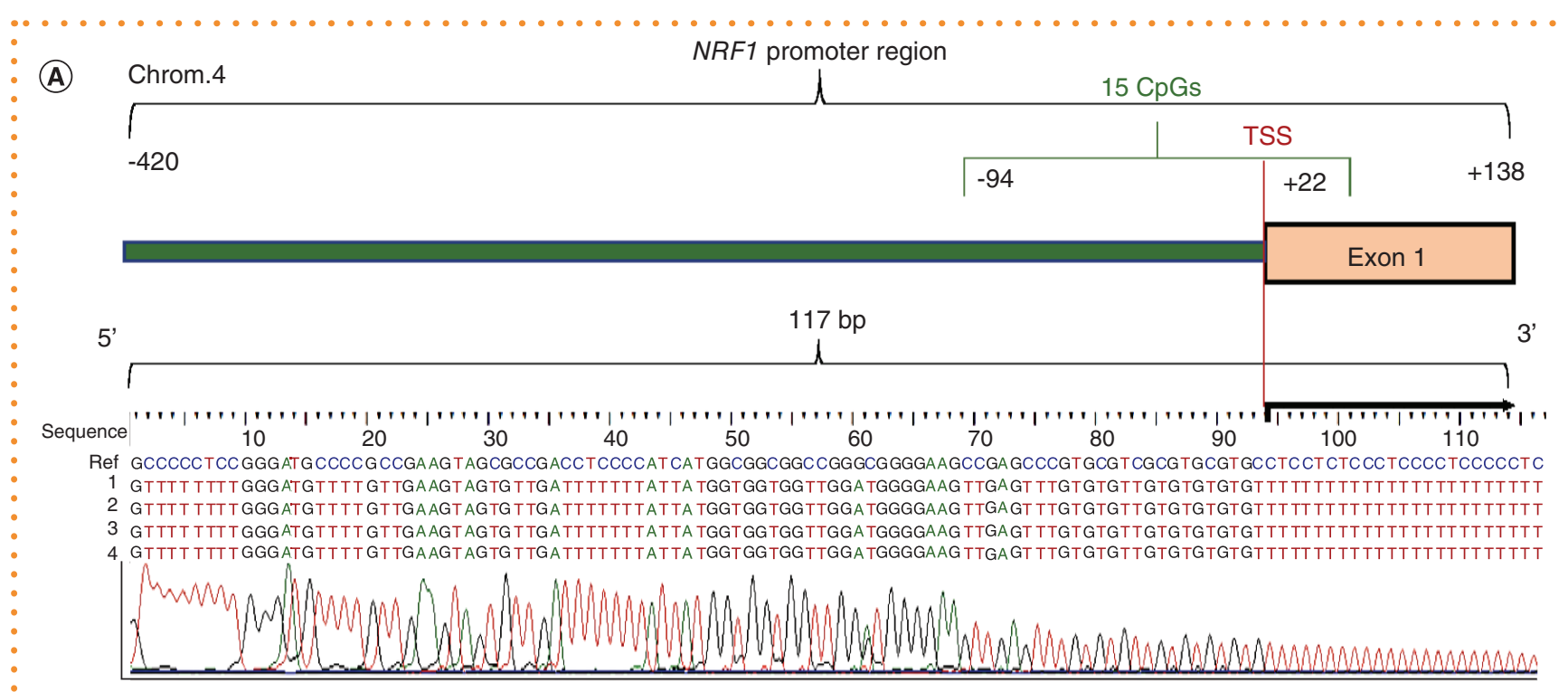

(B)

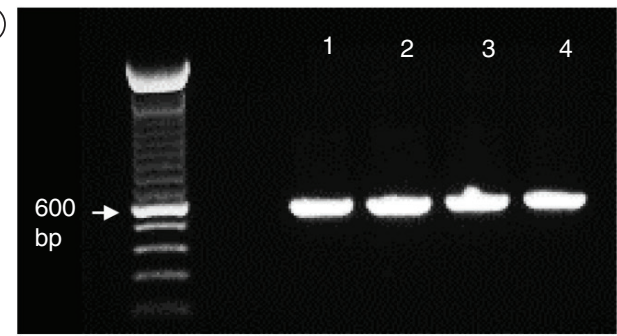

(C)

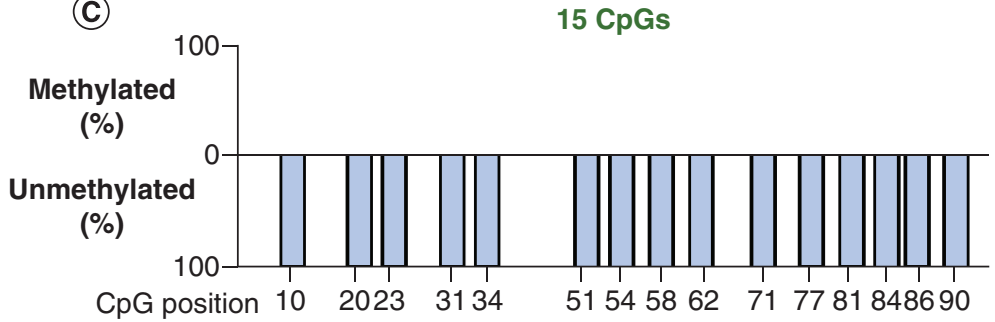

Figure 3. PCR amplification, Sanger sequencing and conversion efficiency of bisulfite-converted sperm DNA. (A) Promoter and TSS of the bovine NRF1 promoter depicting a 117-bp amplicon of four independent samples of Sanger-sequenced bisulfite-converted bull sperm aligned to a reference sequence with representative electropherogram. (B) PCR products from the NRF1 promoter region of bisulfite-treated bull sperm visualized by gel electrophoresis after two rounds of amplification from four independent samples of pooled bull sperm. (C) Methylation status and conversion efficiency of $15 \mathrm{CpG}$ islands from a 117-bp amplicon of the NRF1 gene. ( $n=$ pooled sperm from two bulls for each independent replicate).

bp: Base pair; TSS: Transcriptional start site.

were designed using Meth Primer software (Table 1). Conditions for the first round of PCR were performed in $20-\mu l$ reactions consisting of $10 \mu$ l of GoTaq Hot Start Green Master Mix (2x; cat. no. M5123; Promega) with the addition of $0.4 \mu \mathrm{l}(4 \mathrm{pM})$ of forward and reverse primer, $50 \mathrm{ng}$ of template and $\mathrm{H}_{2} \mathrm{O}$ up to $9.2 \mu \mathrm{l}$. PCR conditions were as follows: $95^{\circ} \mathrm{C}$ for $3 \mathrm{~min}$, followed by 35 cycles of $95^{\circ} \mathrm{C}$ for $30 \mathrm{~s}, 59^{\circ} \mathrm{C}$ for $30 \mathrm{~s}, 72^{\circ} \mathrm{C}$ for $45 \mathrm{~s}$ and a final extension of $72^{\circ} \mathrm{C}$ for $7 \mathrm{~min}$. A second PCR reaction was performed following the same conditions with $5 \mu \mathrm{l}$ of PCR product from the first reaction and water. Success of amplification was determined by gel electrophoresis as previously indicated. Single-band amplicons were identified (Figure 3B), and the remaining PCR product was purified using the QIAquick PCR Purification kit, following manufacturer specifications. For final elution, $15 \mu$ of nuclease-free $\mathrm{H}_{2} \mathrm{O}$ was added to the center of the column, centrifuged and repeated. DNA was quantified by NanoDrop. A minimum of $40 \mathrm{ng}$ of DNA from samples with a $260-/ 280-n m$ purity absorbance ratio of 1.8-1.9 was submitted for Sanger sequencing. Sequencing data were analyzed using BioEdit software (Ibis Therapeutics, CA, USA). Bisulfite conversion efficiency and $\mathrm{CpG}$ methylation status were determined by QUMA software (Figure 3A-C) [12].

The methods described here for evaluation of genomic and epigenomic profiles of mammalian sperm require low sperm input, are cost effective and eliminate overnight DNA extraction. This workflow is beneficial for use in clinical settings in which a limited sperm number from males may require increased assay sensitivity and processing time. Isolation of DNA from samples with $4 \times 10^{3}$ motile sperm using highly optimized buffer conditions was effective and efficient for downstream application (Figures $2 \& 3$ ). Recovery rates of genomic DNA and bisulfite-converted DNA were highly consistent (Table 2) and resulted in successful PCR amplification (Figure 3). Bisulfite treatment of isolated DNA resulted in high conversion efficiency (>98\%; Figure 3). Finally, Sanger sequencing is also compatible with these methods for reliable genomic and epigenomic evaluation of selected amplicons (Figure 3). These techniques describe improved methodology for isolation and methylation analyses of ejaculated mammalian sperm DNA that can be used independently or as a continuous workflow adapted to suit experimental, clinical or laboratory needs. 


\section{AUTHOR CONTRIBUTIONS}

BW Daigneault designed, performed experiments and prepared the manuscript. SK Rajput optimized reagents and provided technical guidance and support. GW Smith provided support and supervised manuscript preparation.

\section{FINANCIAL \& COMPETING INTERESTS DISCLOSURE}

B Daigneault is currently supported by a grant from the Eunice Kennedy Shriver National Institute of Child Health and Human Development of the National Institutes of Health under the award numbers T32HD087166. The authors have no other relevant affiliations or financial involvement with any organization or entity with a financial interest in or financial conflict with the subject matter or materials discussed in the manuscript apart from those disclosed.

No writing assistance was utilized in the production of this manuscript.

\section{OPEN ACCESS}

This work is licensed under the AttributionNonCommercial-NoDerivatives 4.0 Unported License. To view a copy of this license, visit http://creativecommons.org/licenses/ by-nc-nd/4.0/

\section{REFERENCES}

1. Hart $\mathrm{K}$, Tadros NN. The role of environmental factors and lifestyle on male reproductive health, the epigenome, and resulting offspring. Panminerva Med. 61 (2), 187-195 (2019)

2. Ibrahim Y, Hotaling J. Sperm epigenetics and its impact on male fertility, pregnancy loss, and somatic health of future offsprings. Semin. Reprod. Med. 36(3-4), 233-239 (2018).

3. De Jonge C, Barratt CLR. The present crisis in male reproductive health: an urgent need for a political, social and research roadmap. Andrology 7(6), 762-768 (2019).
4. Donkin I, Barres R. Sperm epigenetics and influence of environmental factors. Mol. Metab. 14, 1-11 (2018).

5. Wyck S, Herrera C, Requena CE et al. Oxidative stress in sperm affects the epigenetic reprogramming in early embryonic development. Epigenetics Chromatin 11(1), 60 (2018).

6. Serra O, Frazzi R, Perotti A, Barusi L, Buschini A. Use of FTA(R) classic cards for epigenetic analysis of sperm DNA. BioTechniques 64(2), 45-51 (2018).

7. Griffin J. Methods of sperm DNA extraction for genetic and epigenetic studies. Methods Mol. Biol. 927, 379-384 (2013).

8. Darbandi M, Darbandi S, Khorram Khorshid HR, Akhondi MM, Mokarram P, Sadeghi MR. A simple, rapid and economic manual method for human sperm DNA extraction in genetic and epigenetic studies. Middle East Fertil. Soc J. 23(3), 216-219 (2018).

9. Inci $F$, Ozen MO, Saylan $Y$ et al. A novel on-chip method for differential extraction of sperm in forensic cases. Adv. Sci. 5(9), 1800121 (2018).

10. Daigneault BW, Rajput S, Smith GW, Ross PJ. Embryonic POU5F1 is required for expanded bovine blastocyst formation. Sci. Rep. 8(1), 7753 (2018).

11. Daigneault BW, McNamara KA, Purdy PH et al. Enhanced fertility prediction of cryopreserved boar spermatozoa using novel sperm function assessment. Andrology 3(3) 558-568 (2015)

12. Kumaki Y, Oda M, Okano M. QUMA: quantification tool for methylation analysis. Nucleic Acids Res. 36(Web Server Issue), W170-W175 (2008) 